\title{
脳卒中の装具療法：私のスタンダード 指定発言
}

\section{QOL 向上を目的とした下肢・靴型装具}

\author{
北里大学医療衛生学部リ八学科 前田 真治
}

【緒言】外出する場所や目的に合わせ服や靴を選び，スポーツなどではその競技に合わせ靴 が必要になることは, 日常ごく当然のこととして行っている，一方，脳卒中片麻痺者の歩行 獲得を目的とした装具療法は, 身体機能向上から生活空間の拡大へつなげる重要な治療法で ある.しかし，QOLを視野に入れた場合, 更に一歩進めた障害者の様々なニーズに応えるこ とも必要な要素と考えられる．脳卒中の下肢装具療法をするにあたり，その医学的のみなら ず，社会的要素も加味した QOL 向上のための装具処方について，工夫作製例を紹介し，その 問題点を考えたい.

【処方例】

1. 冠婚用装具

(1)結婚式用短下肢装具 (和装用) : 脳出血による右片麻痺 (26 歳女性). 本人の結婚式に際 し，和装の打掛けを希望し草履を履きたいと言う。そこで，打掛け用草履に金属支柱を付け た短下肢装具を作製, 実際に結婚式で使用した。本人も夢が叶い満足した式が挙げられたと 言っている.

(2)結婚式用短下肢装具 (洋装用) : 脳出血左片麻痺 (21 歳女性). 本人の強いウェディングド レスへの希望から, 装具を希望. 靴はウェディングシューズに準じ白のデザイン. 結婚式は 足下も気にすることなく行え，満足であったと言っている.

(3)冠婚用短下肢装具（和服用）：息子の結婚式に和服用の装具を希望した脳出血左片麻痺者 (54 歳女性). 市販の草履を用い短下肢装具を作製。式の後も冠婚用に使用している.

2. 趣味・スポーツ用装具

(1)釣り用長鞉型装具：病前より川釣りが趣味であった脳出血右片麻痺（58 歳男性).川の中 に入れる長鞉型の装具を希望. 前方を開けカウンター部分の側方をガラス繊維で固めた長鞉 型装具を作製，釣りに使っている.

(2)ゴルフ用短下肢装具：ゴルフが趣味で，スパイク靴を希望した脳梗塞者 (60 歳男性)。市 販のゴルフシューズを用い短下肢装具作製. スパイクのため多少足を高く上げる歩容になる が, 力の入るショットが可能になり，他の仲間と同じょうにでき満足している.

(3)スケート用短下肢装具：市販のスケートシューズでも足関節部の固定がある程度されるが, まだ不安定ということで作製（日常生活は Shoehorn Brace で杖なし歩行）．市販のスケート 靴に金属支柱を取付けた短下肢装具を作製。スケートを楽しんでいる。

3. 服装に合わせた短下肢装具

病前は衣服に合わせた靴を履き替えながら生活していた脳梗塞者 (60 歳男性)。短下肢装 具に合わせた種々の靴を作製. TPOに合わせて靴を選んでいる.

【考案】保険や身障手帳で作製できる靴では，社会生活を当たり前に暮らすにはまだ障害者 は健常者との隔たりが大きい. 病気だから，障害者だからという理由で制限を受けるのは自 由度が小さい. 今後, 脳卒中障害者に用いる装具は, 機能的障害に合わせるだけでなく, 個々の QOL 向上の目的に合わせ，常に障害者のための QOL を考慮した装具の処方もすべき であると思われる。 